\title{
モノカラー再生系における空間処理一I
}

\section{—OTF 修正空間フィルターによるビジコンプリアンプ雑音の効果の低減—}

\author{
日本コロムビア株式会社 米山正秀
}

モノカラー再生画像の $S / N$ を改善することを目的として，再生系での空間処理を提案し，シス テム伝達関数を 2 次元的に修正する空間フィルターについて検討した。理論検討の結果，搬送伝送 帯域におけるビジコンプリアンプ雑音の低減率は，低搬送チャネルで約 $5 \mathrm{~dB}$ ，高搬送チャネルで 約 $9 \mathrm{~dB}$ となる。また，実際に空間フィルターを製作し，コヒーレント空間処理実験を行なった結 果, ほぼ理論値に近い結果が得られた。

\section{1. ま がき}

1 枚の白黒フィルム上に複数の 2 次元画像を異なった 空間周波数で同時に多重記録する方式は，すでにいくつ か提案されている。乙れらの方式のうち，記録系はほぼ 同じであるが再生系に执いて単色点光源を用いてフィル ムを照射し, 純光学的に多重画像から個々の画像を分離 再生する方式 ${ }^{1)}$, 一方, テレビ系と組合せてフィルム 上の多重画像をテレビカメラの撮像管面上に投影し，い ったん電気信号に変換し電気回路系に拈いて個々の画像 を分離しテレビ受像機上に再現する方式 ${ }^{2)}$ とがある.

特に多重化する画像情報として, 被写体の3 個の色彩 情報 $R, G, B$ について考えると, 前者の再生方式の一 例亡して Mueller の研究3'があり，後者の再生方式はモ ノカラー方式と呼ばれている。

筆者は先にモノカラ一記録再生システムのシステム検 討を行ない，システム雑音による搬送多重画像の雑音に ついて考察した4).

この結果, 総合システム伝達関数の特性を電気回路系 で修正することにより，高空間周波数領域で多重されて いる画像の $S / N$ が極度に劣化することを示した。

そしてさらに，写真乳剂に対する線形記録の条件とし ては，低コンスラスト露光と低ガンマ処理であり，ての 結果， $S / N$ はますます劣化する傾向にあることが指摘 された.

したがって，モノカラ一方式の画質を実用的なレベル にまで向上させるためには, 従来よりあ $S / N$ を改善さ

\footnotetext{
“Spatial Filtering Process in Monocolor Reproducing System (I) - The Reduction of the Vidicon Pre-amplifier Noise by OTF Correcting Spatial Filter_by Masahide Yoneyama (Nippon Columbia Co., Ltd., Kawasaki)
}

せる必要がある。本論文はモノカラー再生像の $S / N$ を 向上させることを目的として, 再生システムにおいてコ ヒーレント空間処理を行なうととを提案する5).

そして, システムの伝達関数を 2 次元的に修正する OTF 修正空間フィルターについて検討し，この空間フ ィルターを採用することによる雑音低減効果について考 察した。

本論文においても，前回の報告 ${ }^{4)}$ の結果に従い，次の 仮定に基づいている.

（1）モノカラーシステムの総合伝達関数はフィルム のレスポンス関数とビジコンビームアパーチャーレスポ ンス関数によって決定され，それらはガウス誤差関数に よって近似できる.

（2）フィルムに対しては線形記録の条件を満たすと とにより，フィルムをはじめ，システム構成要素はす心゙ て線形であると考える。

（3） システム雑音としては，フィルム粒状性雑音と ビジコンプリアンプ雑音に限定する.

\section{2. 再生システムにおける空間処理}

\section{$2.10 \mathrm{TF} *$ 修正空間フィルターの検討}

従来のモノカラー方式に拉ける多重信号の通過経路の モデルを示すと図 1 になる4).

図1において, $H_{1}(u, v) ;$ フィルムのレスポンス関数

$H_{2}(u, v)$; ビジコンビームアパーチャーレスポンス 関数

$F(u, v)$; 多重化画像の空間周波数スペクトル

$T(u)$; 電気的補正回路系の伝達関数 


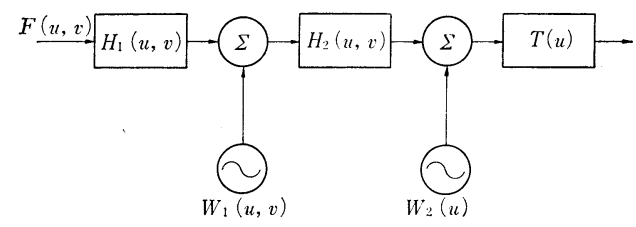

図 1 従来のモノカラー方式の主要部のシステムモデル System model for the mainparts of the usual Monocolor System.

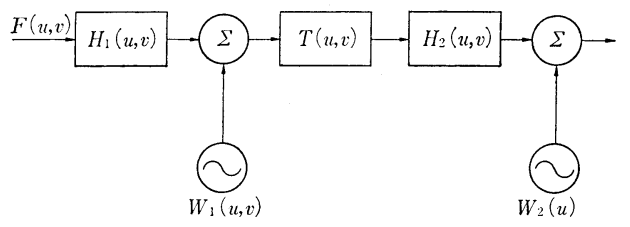

図 2 空間修正系を有する主要部のシステムモデル

System model for the mainparts of the spatial correcting Monocolor System.

$\mid \begin{aligned} & W_{1}(u, v) ; \text { フィルム粒状性雑音のパワースペクトル } \\ & W_{2}(u) ; \text { プリアンプ雑音のパワースペクトル }\end{aligned}$ ただし $u ， v$ はフィルム面に括ける $x$ 方向および $y$ 方向の空間周波数を表わすすのとする.

図 1 のシステムに対し，今度はフィルム系とビジコン 系の間に空間的修正伝達系を插入するようなシステムを 新たに提案する。

このシステムのモデル罒を図 2 に示している.

図 2 において，T(u,v) は修正伝達系の伝達関数であ る. $T(u, v)$ は図 2 のシステム伝達関数がフラットであ るという条件より決定され，(1)式のようになる677).

$$
T(u, v)=\frac{1}{H_{1}(u, v) \cdot H_{2}(u, v)}
$$

ここで, $H_{1}(u, v)$ および $H_{2}(u, v)$ はガウス誤差関 数で近似でき，(2)式のように表現できる ${ }^{4)}$.

$$
\left.\begin{array}{l}
H_{1}(u, v)=\exp \left(-\frac{u^{2}+v^{2}}{2 \sigma_{1}^{2}}\right) \\
H_{2}(u, v)=\exp \left(-\frac{u^{2}+v^{2}}{2 \sigma_{2}{ }^{2}}\right)
\end{array}\right\}
$$

（2）式を（1）式に代入すると $T(u, v)$ の伝達関数を 得る.

この場合， $H_{1}(u, v), H_{2}(u, v)$ が $u ， v$ に対して等 方的であるので $T(u, v)$ 屯等方的となる.

$$
T(u, v)=\exp \left(\frac{u^{2}+v^{2}}{2 \sigma^{2}}\right)
$$

ただし，

$$
\sigma=\frac{\sigma_{1} \sigma_{2}}{\sqrt{\sigma_{1}^{2}+\sigma_{2}^{2}}}
$$

いま，(3)式の $T(u, v)$ の特性を考えると $u, v$ の 増大とともに高い相対利得を要求されるので，ある限定

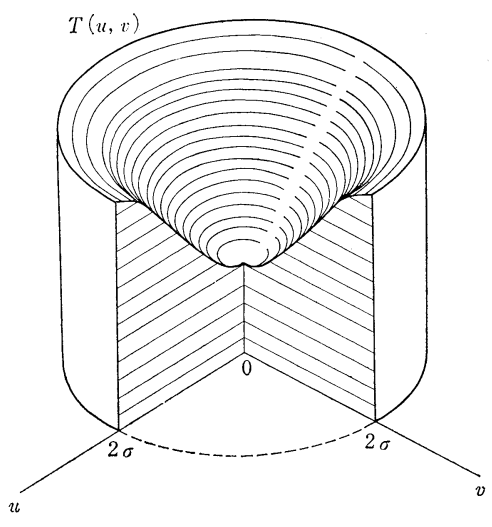

図 $3 T(u, v)$ の特性

The characteristic of $T(u, v)$.

した $u$, vの範囲内でしか実現性がない.

したがって，有効伝達領域を（5）式に限定する.

$$
\sqrt{u^{2}+v^{2}} \leqq 2 \sigma
$$

(5) 式の等号の成立する空間周波数では, $H_{1}(u, v)$ と $H_{2}(u, v)$ の積の伝達関数は $u=v=0$ のときに比較 して $13.5 \%$ に低下する. これは $H_{1}(u, v) \cdot H_{2}(u, v)$ に $\sqrt{u^{2}+v^{2}}=2 \sigma$ を代入すると 0.135 を得るからであ る. 結局, $T(u, v)$ としては,

$$
T(u, v)= \begin{cases}\exp \left(\frac{u^{2}+v^{2}}{2 \sigma^{2}}\right), & \sqrt{u^{2}+v^{2}} \leqq 2 \sigma \\ 0, & \sqrt{u^{2}+v^{2}}>2 \sigma\end{cases}
$$

のような特性を要求される.

（6）式で示される $T(u, v)$ の特性を図示すると図 3 に示すようになる.

\section{$2.2 \mathrm{OTF}$ 修正空間フィルターによる搬送伝送帯域の 雑音低減効果}

電気的修正系 $T(u)$ の代わりに空間修正伝達系 $T(u$, v）を用いると，ビジコンプリアンプ雑音は補正特性の 影響を受けないので，大幅に低减させることが期待され る.

乙の低減効果は，高い周波数で搬送されている伝送帯 域ほど著しくなることは容易に想像しうる.

ここでは, 高空間周波数における搬送伝送信号の電気 的帯域フィルター通過後の雑音量が，空間フィルター $T(u, v)$ による空間処理によりどの程度低減するかを検 討する.

この場合のシステム図を図 4 に示す.

四 4 において， $B(u)$ は多重信号よりおのおのの信号 を分離するための電気的帯域フィルターであり, その伝 達特性は（7）式のように理想化できる. 


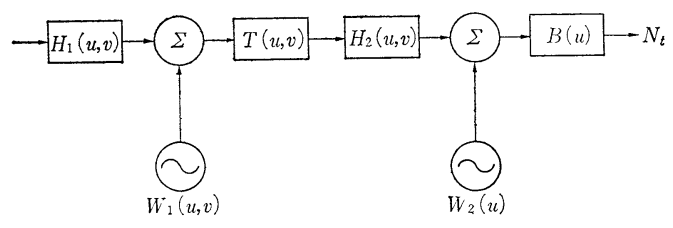

図 4 搬送信号経路のモデル

System model for the passing way of a carrier signal

$$
|B(u)|= \begin{cases}1 & u_{0}-\Delta u \leq u \leq u_{0}+\Delta u \\ 0 & u<u_{0}-\Delta u, \quad u>u_{0}+\Delta u\end{cases}
$$

また， $N_{t}$ はフィルム粒状性雑音㐨よびビジコンプリ アンプ雑音による分離フィルター出力端での雑音パワー であり，（8)が成立する

$$
N_{t}=N_{t 1}+N_{t 2}
$$

ただし $\left\{\begin{array}{c}N_{t 1}, \text { フィルム粒状性雑音による雑音パワー } \\ N_{t 2}, \text { ビジコンプリアンプ雑音による雑音パ } \\ \text { ワー }\end{array}\right.$

さらに， $N_{t 1}$ および $N_{t 2}$ は（9)，（10）式によって それぞれ示される

$$
\left\{\begin{aligned}
N_{t 1}= & \int_{-\infty}^{\infty} \int_{-\infty}^{\infty} W_{1}(u, v) \mid T(u, v) \cdot H_{2}(u, v) \\
& \left.\cdot B(u)\right|^{2} d u d v \\
N_{t 2}= & \int_{-\infty}^{\infty} W_{2}(u)|B(u)|^{2} d u
\end{aligned}\right.
$$

ここにおいて， $W_{1}(u, v)$ および $W_{2}(u)$ は, 先の論 文4で屯指摘したように，いま考えている伝送領域

$\sqrt{u^{2}+v^{2}} \leq 2 \sigma$ においては両方とあ平坦であると考えら れるので (11) 式が成立する.

$$
\left.\begin{array}{l}
W_{1}(u, v)=A_{1} \\
W_{2}(u)=A_{2}
\end{array}\right\}
$$

いま（2)，(6)，(7)，(11) 式を（9）式，(10)式 に代入すると（12），(13）式を得る (付録).

$$
\begin{aligned}
N_{t 1} & =A_{1} \iint_{S} \exp \left(\frac{u^{2}+v^{2}}{\sigma_{1}^{2}}\right) d u d v \\
& =A_{1} \sigma_{1}^{2}\left[\exp \left(\frac{2 \sigma}{\sigma_{1}}\right)^{2}\left(\alpha_{1}-\alpha_{2}\right)+S\left(\alpha_{2}\right)-S\left(\alpha_{1}\right)\right] \\
N_{t 2} & =A_{2} \int_{u_{0}-\Delta u}^{u_{0}+\Delta u} d u=2 A_{2} \Delta u
\end{aligned}
$$

ただし，

$$
S(\alpha)=\int_{0}^{\alpha} \exp \left(\frac{2 \sigma}{\sigma_{1}} \cos \alpha \cdot \sec \theta\right)^{2} d \theta
$$

(12) 式に抽りる $\alpha_{1}, \alpha_{2}$ は空間フィルター $T(u, v)$ の有効空間周波数領域と分離帯域フィルター $B(u)$ の領 域と $u-v$ 平面で図 5 の関係にある.

次に図 1 に示す従来のモノカラー方式と，空間処理を する方式との雑音量の比較を行なう.

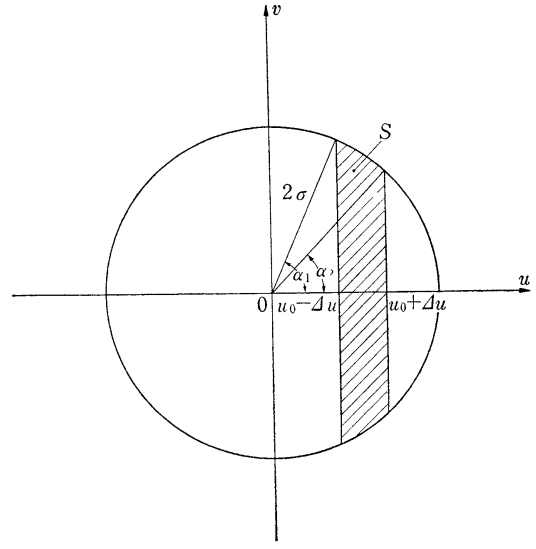

図 5 積分領域之 $\alpha_{1}, \alpha_{2}$ の関係

The relation between $\alpha_{1}, \alpha_{2}$ and integral region.

この場合, 雑音量としては, 電気的带域フィルターの 出力端で考える 筆者の前回の報告によれば4， 1 次元 補正伝達関数 $T(u)$ による往来のモノカラー方式の分離 帯域フィルター出力での雑音パワーは (15), (16) 式で 示される

つまり $\left\{\begin{array}{l}N_{01}, \text { フィルム粒状性雑音によるパワー } \\ N_{02}, \text { ビジコンプリアンプ雑音によるパワー }\end{array}\right.$ とすると，

$$
\left\{\begin{array}{l}
N_{01}=A_{1} \sigma_{2} \sqrt{\pi} \Phi_{1}\left(u_{0}\right) \exp \left(\frac{u_{0}}{\sigma} \tan \phi\right)^{2} \\
N_{02}=A_{2} \Phi_{2}\left(u_{0}\right) \exp \left(\frac{u_{0}}{\sigma} \tan \phi\right)^{2}
\end{array}\right.
$$

ただし，

$$
\left.\begin{array}{l}
\Phi_{1}\left(u_{0}\right)=\int_{u_{0}-\Delta u}^{u_{0}+\Delta u} \exp \left(\frac{u}{\sigma_{1}}\right)^{2} d u \\
\Phi_{2}\left(u_{0}\right)=\int_{u_{0}-\Delta u}^{u_{0}+\Delta u} \exp \left(\frac{u}{\sigma}\right)^{2} d u
\end{array}\right\}
$$

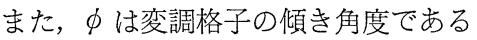

いま, 従来のモノカラー方式に比較して, 空間処理モ ノカラー方式の搬送伝送帯域における雑音低减率を次の ように定義する

粒状性雑音の低減率, $\rho_{t 1}=\sqrt{N_{t 1} / N_{01}}$

$\left\{\right.$ プリアンプ雑音の低減率, $\rho_{t 2}=\sqrt{N_{t 2} / N_{02}}$

(12)，(13)，(15)，(16)，(18）式より，それぞれの低 減率は，

$$
\begin{aligned}
& \rho_{t 1}=\sqrt{\frac{\sigma_{2} V \bar{\pi} \Phi_{1}\left(u_{0}\right) \exp \left(\frac{u_{0}}{\sigma} \tan \phi\right)^{2}}{\sigma_{1}^{2}\left\{\exp \left(\frac{2 \sigma}{\sigma_{1}}\right)^{2}\left(\alpha_{1}-\alpha_{2}\right)+S\left(\alpha_{2}\right)-S\left(\alpha_{1}\right)\right\}}} \\
& \rho_{t 2}=\sqrt{\frac{2 \Delta u}{\Phi_{2}\left(u_{0}\right) \exp \left(\frac{u_{0}}{\sigma} \tan \phi\right)^{2}}}
\end{aligned}
$$


表 1 数値計算のためのパラメーターの值

The value of parameters for numerical calculas.

\begin{tabular}{c|c||c|c||c|c}
\hline \hline$\sigma_{1}$ & $30(1 / \mathrm{mm})$ & $\sigma_{2}$ & $22(1 / \mathrm{mm})$ & $\Delta u$ & $2.4(1 / \mathrm{mm})$ \\
\hline
\end{tabular}

となる.

\section{$2.3 \rho_{t 1}, \rho_{t 2}$ の数值計算による評価}

数值計算を行なう前提としての各パラメーターの決定 は，前回の報告4) と同じ考え方に基づいている.

つまり写真フィルムとしては $16 \mathrm{~mm}$ 白黒フィルム, ビジコンとしては 1 インチビジコン 8507 を用い，それ ぞれの代表的なカタログデータより $\sigma_{1}$ および $\sigma_{2}$ を決 定した.

さらに，すべて $16 \mathrm{~mm}$ フィルム面上の空間周波数に 統一して検討した。 パラメーターの值を表 1 亿示す.

表 1 のパラメーターの值を用いて， $\rho_{t 1} ， \rho_{t 2}$ を IBM のシステム 360 モデル 75 で数值計算を行なった。 との 結果を図 6 , 図 7 亿示している.

コンピューター解析の結果を概観すると, 空間処理に より従来にくらべプリアンプ雑音の影響は大幅に減少す

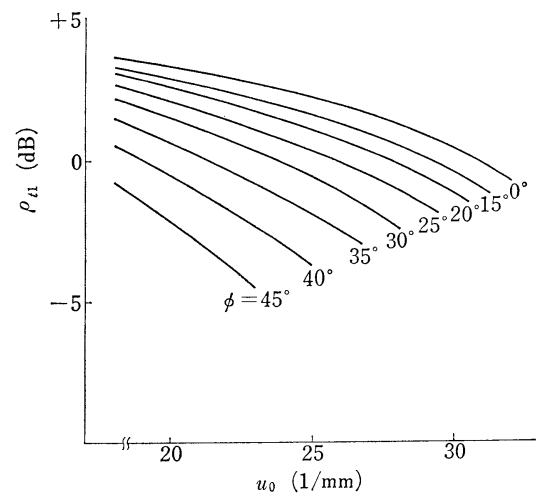

図 6 空間処理による粒状性雑音の低減率

The rate of reduction to film granularity noise by spatial filtering process.

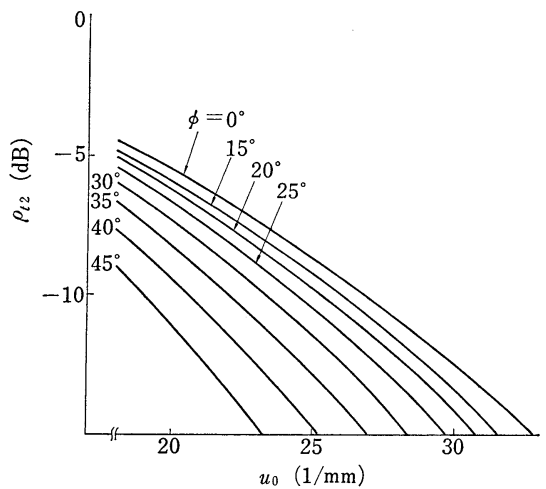

図 7 空閲処理によるプリアンプ雑音の低減率 The rate of reduction to vidicon pre-amplifier noise by spatial filtering process.
る.

この傾向は多重するキャリヤ空間周波数 $u_{0}$ が高くな るほど，また変調格子の傾斜角 $\phi$ が大きくなるほど(つ まり $v_{0}$ が大きいほど）顕著である，たとえば $u_{0}=25$ $1 / \mathrm{mm}, \phi=10^{\circ}$ (通常のモ)カラーの higher channel に 相当）では，約 $9 \mathrm{~dB} の$ 改善となる．また $u_{0}=201 / \mathrm{mm}$, $\phi=15^{\circ}$ (通常のモノカラーの lower channel に相当) では, 約 $5 \mathrm{~dB}$ の改善となる (図 7 参照).

しかしながら、フィルム粒状性雑音に対する改善効果 はないととが示されている(図6 参照).

とれは空間処理を行なっても粒状性雑音は相変わらず 補正特性の影響を受けるからである。

\section{3. 実験}

\section{1 実験光学系}

前章までに議論した空間処理は非常に概念的なあので あったが，とれはコヒーレント光の回折現象を利用して 具体化するととができる ${ }^{899}$.

Fraunhofer 回折について考えると，開口面の座標之 回折面の座標を図 8 のように設定すると, 開口面の振幅 透過率分布 $a(x, y)$ 之回折像の振幅分布 $W(\xi, \eta)$ は (21)式の関係がある ${ }^{10)}$.

$$
\begin{aligned}
W(\xi, \eta) & =\text { const } \int_{-\infty}^{\infty} \int_{-\infty}^{\infty} a(x, y) \exp \left\{-j \frac{2 \pi}{\lambda f}(\xi x\right. \\
& +\eta y)\} d x d y \equiv \text { const } A(u, v)
\end{aligned}
$$

(21) 式に扔いて

$$
\left\{\begin{array}{l}
\lambda ; \text { 光源の波長 } \\
f ; \text { レンズの焦点距離 } \\
A(u, v) ; a(x, y) \text { のフーリエ変換 }
\end{array}\right.
$$

つまり, Fraunhofer 回折像の振幅分布は透過物体の 振幅透過率分布のフーリエ変換に比例する.

以上の議論に基づき，空間処理を実現するための光学

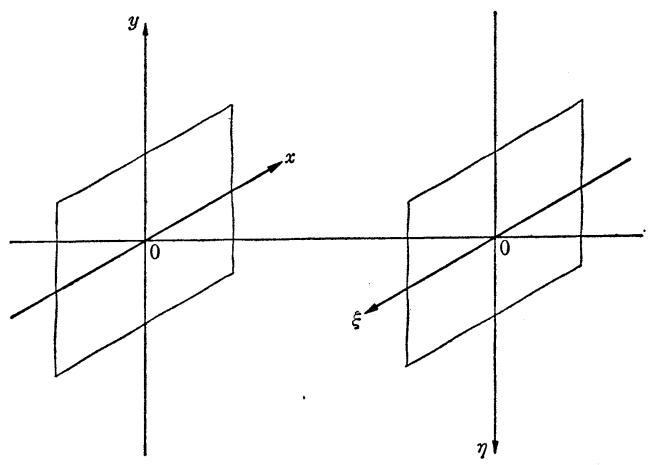

図 8 開口面と回折面の座標

The coordinate of the aperture plane and the diffraction plane. 
系を図 9 に示す。図 9 の光学系は再回折光学系之 して一般によく知られたあのである.

(21) 式の議論より, 図 9 の回折面に空間フィル ター $T(u, v)$ を配置すると，フィルタリングさ れた像がビジコン面に再結像される.

(21) 式加あ推察されるように, 図 9 の光学系 においては，開口面の物体の空間周波数 $u, v$ と 回折面のスペクトル分布の寸法 $\xi, \eta$ とは (22) 式の関係になる.

$$
\left.\begin{array}{l}
\xi=\lambda f u \\
\eta=\lambda f v
\end{array}\right\}
$$

現在のモノカラーフィルムの多重周波数は約 20 (1) $\mathrm{mm})$ と $25(1 / \mathrm{mm})$ である. また, 光源としては $\mathrm{He}-\mathrm{Ne}$ レーザー（ $\lambda=6,328 \AA)$ を用いた。

したがって，実用的な寸法を持つ空間フィルターを得 るためには， $f$ を相当大きくする必要がある.

実験には $f=500 \mathrm{~mm}, f^{\prime}=635 \mathrm{~mm}$ の $\mathrm{L}_{2}, \mathrm{~L}_{3} 2$ 枚 のレンズを用いた．とれにより，25(1/mm) の変調格子 に対しては, 回折面で中心から約 $8 \mathrm{~mm}$ の点に 1 次スペ クトルが現われるととになり，空間フィルターの製作あ 比較的に容易となった。

写真 1 に実験に用いた光学系の写真を示す.

\section{2 空間フィルターの製作}

図 9 の光学系の開口面に振幅透過率分布 $\hat{a}(x, y)$ の多 重記録されたフィルムを执，回折面に振幅透過率 $\hat{T}$ $(u, v)$ の空間フィルターを拝くと，レンズ $\mathrm{L}_{3}$ の後側焦 点面であるビジコン面にフィルタリングされた像が得ら れる.

(ことにおいて，へ印は振幅に対する值を示し， 八印 のないものは強度に対する值を示し，一般に強度=|振 幅! 2 関係がある).

この像の振幅分布 $\hat{i}\left(x^{\prime}, y^{\prime}\right)$ に対するフーリエ変換を $\hat{I}(u, v)$ とすると (23) 式が成立する.

$$
\hat{I}(u, v)=\hat{T}(u, v) \cdot \hat{A}(u, v)
$$

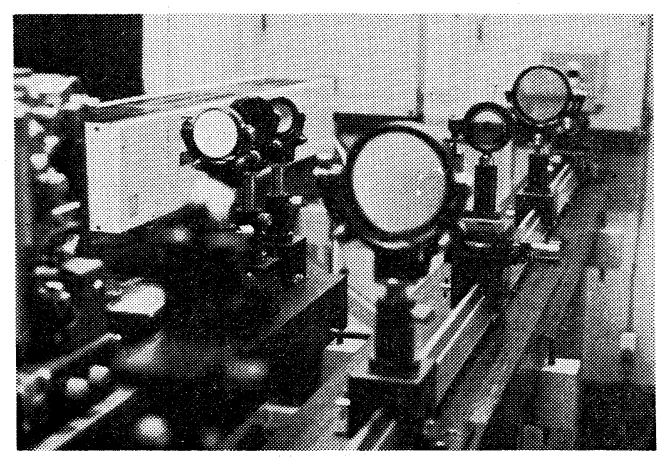

写真 1 実験光学系の写真

The photograph of optical system used by experiments.

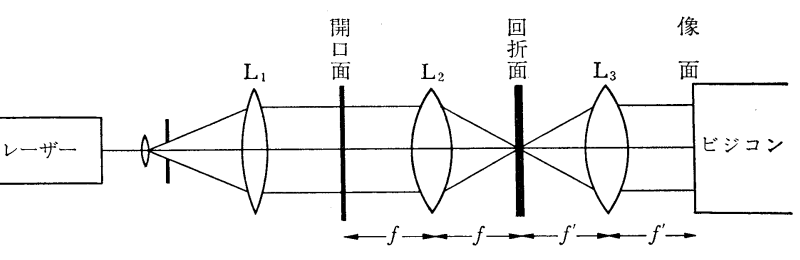

図 9 実験に用いたフィルタリング光学系

The spatial filtering optical system used by experiments.

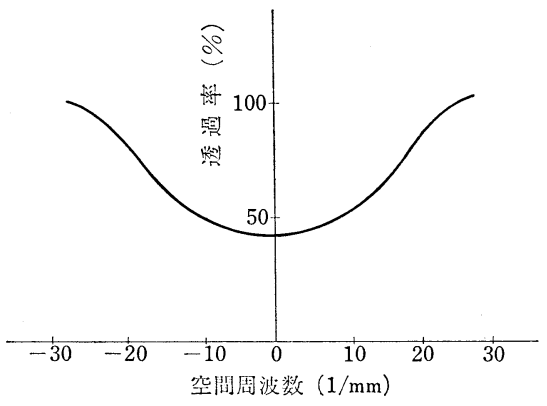

図 10 実験に用いた空間フィルターの特性の一例

An example of spatial filter characteristic used by experiments.

ただし， $\hat{A}(u, v)$ は $\hat{a}(x, y)$ のフーリエ変換である.

ここにおいて，撮像管などの受光器は一般に面上の光 強度分布に感じるので実効的には,

$$
I(u, v)=|\hat{I}(u, v)|^{2}=T(u, v) \cdot A(u, v)
$$

(24) 式において, $T(u, v)$ は前章で議論した空間フィ ルターの伝達関数, $\hat{T}(u, v)$ はコヒーレント空間処理の 実験のための空間フィルターの特性で，(25)式の関係が ある。

$$
\hat{T}(u, v)=\sqrt{T(u, v)}
$$

図 10 に実験に用いた $\hat{T}(u, v)$ の特性の一例を示す. また，写真 2 に実際の空間フィルターの写真を示す.

この空間フィルターはガラス板にインコーネルを蒸着

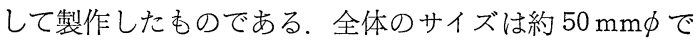
あるが, インコーネルの蒸着されている有効サイズは約 $16 \mathrm{~mm} \phi$ である. また，乙の空間フィルターは蒸着物質

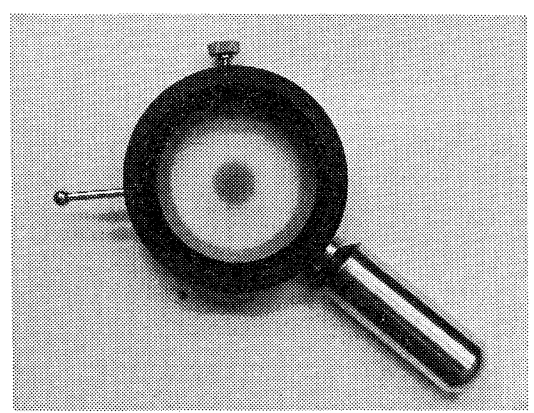

写真 2 実験に用いた空間フィルター

The spatial filter used by experiments. 
がインコーネルであるため, 分光透過率特性はほぼ平坦 である。

\section{3 実験結果}

空間フィルター $\hat{T}(u, v)$ にる搬送信号レベルの増大 率について測定した.

手順としては最初に空間フィルターを用いずに，フィ ルムの像を直接ビジコン面に投影し，電気信号に变換し た後, 色信号分離帯域フィルター出力端での搬送信号レ ベルを測定する。とのとき同時に低域の非搬送信号レ心゙ ル屯測定する．次に，空間フィルターを挿入すると光量 が低下するので，フィルムを照射するレーザー強度を増 加し，低域フィルター出力の非搬送信号レベルが空間フ ィルターを使用しないときの值と等しくなるように調整 する.

この状態で，色分離フィルター出力端での搬送信号レ ベルを測定し，前回のレベルと比較する.

以上のようにして得られた測定結果を表 2 に示す.

坠 2 搬送信号增大率の実験結果 (プリアンプ維音低隇率の実匰結果)

The experimental results of rate of increasement of the carrier signals.

\begin{tabular}{|c|c|c|}
\hline チャネル & 搬送周波数 $u_{0}$ & 信号増大率 \\
\hline 低 & $\longrightarrow$ & $0 \mathrm{~dB}$ \\
\hline 搬送チャネル（低） & $20(1 / \mathrm{mm})$ & $3 \sim 4 \mathrm{~dB}$ \\
\hline 搬送チャネル（高） & $25(1 / \mathrm{mm})$ & $6 \sim 8 \mathrm{~dB}$ \\
\hline
\end{tabular}

表 2 に示している信号増大率は，空間処理によるビジ コンプリアンプ雑音の低減率に等しいととになる。つま り，空間フィルターを挿入し，非搬送信号レベルを合わ せた状態で，各搬送信号レベルを空間処理しないときの 值に等しくするためには，各搬送チャネルの利得を表 2 に示す值だけ低下させなければならない，乙のとき，電 気的雑音（ビジコンプリアンプ雑音）の量は表 2 に示す 值だけ減少することになるので，表 2 は電気的雑音の低 減率を示すととになる。

実験によって求めた低減率は, 理論值 $\rho_{t 2}$ と比較的よ い一致が得られた. 従来のモノカラー方式の $S / N$ 值に ついては，高搬送チャネルの帯域フィルター出力端での ビジコンプリアンプ雑音による $S / N$ が約 $26 \mathrm{~dB}$ である という実験結果が報告されている2).

参考として， $16 \mathrm{~mm}$ SMPTE 解像度フィルムを用い て空間処理をしたときと，しないときの再生画像を比較 した.

写真 3 は空間フィルターを使用しないとき，写真 4 は 空間フィルターを用いてフィルタリングしたときのテレ ビ受像機上の再生画像である，使用したフィルムおよび 印画紙のレスポンス特性のため，乙の写真では大きな差 は認められないが，テレビ画面で直接比較すると，クサ

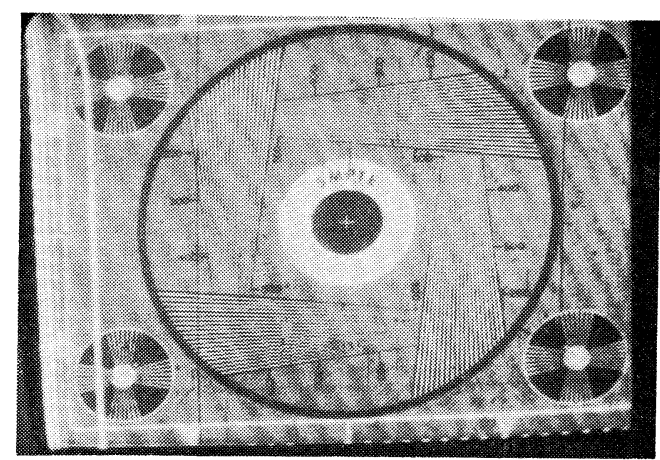

写真 $316 \mathrm{~mm}$ SMPTE 解像度フィルムの TV 受像機再生画像（空間フィルターなし）

The reproduced image of $16 \mathrm{~mm}$ SMPTE resolution film. (Without spatial filter)

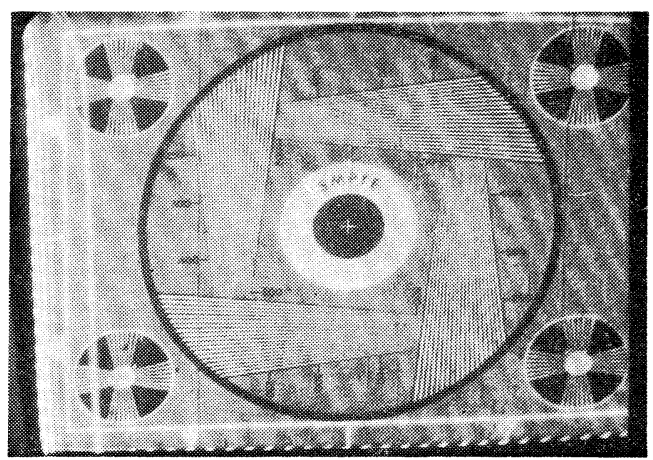

写真 $416 \mathrm{~mm}$ SMPTE 解像度フィルムの TV 受像機再生画像 (空間フィルターあり)

The reproduced image of $16 \mathrm{~mm}$ SMPTE resolution film. (With spatial filter)

ビ部分のコントラストが大幅に増大するのがわかる。

な拝，画中央左下にスペックルノイズパターンが現 われているが，乙れはレーザーのようにコヒーレンシイ の高い光源を使用しているために生じる量子雑音であ る.

\section{4.むす び}

モノカラーシステムを構成する 2 次元伝達要素のう ち，フィルム乳剂とビジコンの伝達特性が最も問題のあ るととに注目し，フィルムレスポンス関数およびビジコ ンビームアパーチャーレスポンス関数を等方的な 2 次元 ガウス関数で近似できると考えて，乙れらのレスポンス 関数を空間処理により 2 次元的に修正する空間フィルタ 一 $T(u, v)$ を提案した。 また，乙の空間フィルターによ る搬送伝送带域の雑音低減率について検討し, 数值計算 結果を求めた.

この結果, ビジコンプリアンプ雑音は大幅に低減する が，フィルム粒状性雑音に対しては勃果がないととが明 
らかとなった，次に，実際に空間フィルターを製作し， コヒーレント光学系で空間処理実験を行なった結果, プ リアンプ雑音低減率は理論值とよい一致が得られた.

しかし，よりいっそう画質を改善するためには，フィ ルム粒状性雑音屯低減する必要があり, てれが残された 問題点である，乙の件については，本論文では触れなか ったが，次の論文報告する。

最後に，日頃ご指導，で鞭挥をいただいております慶 応義塾大学 藤田広一教授, 栗田正一教授, および本研 究発表の機会を与えて下さった高木研究部長に謝意を表 するとともに, 特に本研究に対して有益なで意見, で討 論をいただきました早稲田大学 大頭 仁教授に樑謝しま ఫ.

(昭和 47 年 9 月 4 日受付)

\section{〔参考 文 献〕}

1) P. F. Mueller: Linear Multiple Image Storage, Appl. Opt., 8, 2 (1969) 267

2) 井口, 副島: 白黑フィルムを用いたモノカラー方式, 放送技術, 12 (1966)

3) P. F. Mueller: Color Image Retrieval from Monochrome Transparencies, Appl. Opt., 8, 10 (1969) 2051

4) 米山正秀: モノカラー記録再生系のシステム研究 〔2 次元領域に 招ける検討】，テレビ誌，27，2 (1973) 25

5) 米山。高木: モノカラーシステム再生系における空間情報処理, テレビ全大予，12-1 (1972)

6) 辻内順平：最近の像修正，地物，37，3 (1968) 274

7) J.L. Horner: Optical Spatial Filtering with the Least Mean Square Error Filter, JOSA, 59, 5 (1969) 553

8) 三橋慶喜: アナログ光演算，忘物，39，7 (1970) 688

9）辻内順平: 光の空間情報の処理, 昭 45 年電気四学会連大予, S 9-7

10）井上，佐柳編：印写工学 I, 共立出版

\section{〈付録〉}

（13）式の方は問題ないので，(12)式の誘導について考 える。（9)式は次のようになる。

$$
N_{t 1}=A_{1} \int_{u_{v}-\Delta u}^{u_{0}+\Delta u} \int_{-\phi(u)}^{\phi(u)} \exp \left(\frac{u^{2}+v^{2}}{\sigma_{1}{ }^{2}}\right) d v d u \quad \text { (付・1) }
$$

ことにおいて, 図5ょり,

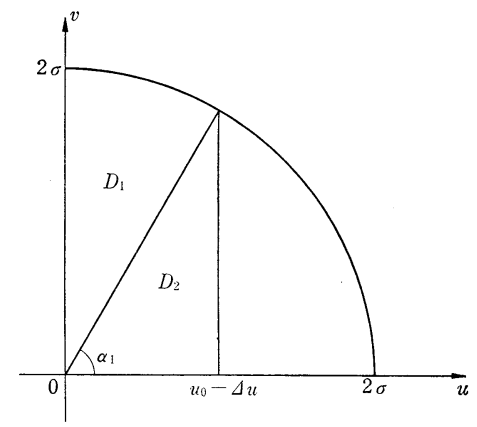

$$
\phi(u)=\sqrt{4 \sigma^{2}-u^{2}}
$$

(付・1) 式の変数を（付・3）式のように極座標に変換 すると，

$$
\left.\begin{array}{l}
u=r \cos \theta \\
v=r \sin \theta
\end{array}\right\}
$$

（付・1）式は（付・4）式のように書きかえられる.

$$
N_{t 1}=2 A_{1} \iint_{D} \exp \left(\frac{r^{2}}{\sigma_{1}^{2}}\right) r d r d \theta \quad \text { (付・4) }
$$

（付・4）式の積分領域 $D$ は図 5 の斜線部分 $S$ と次の 関係にある.

$$
D=S / 2
$$

いま， $D$ を付・図 1 亿示すように 4 分割すると， D は,

$$
D=D_{3}+D_{4}-\left(D_{1}+D_{2}\right) \quad \text { (付 - 6) }
$$

さらに,

$$
\begin{aligned}
& \iint_{D_{1}} \exp \left(\frac{r^{2}}{\sigma_{1}^{2}}\right) r d r d \theta=\int_{0}^{2 \sigma} \exp \left(\frac{r^{2}}{\sigma_{1}^{2}}\right) r d r \int_{\alpha_{1}}^{\pi / 2} d \theta \\
& =\frac{\sigma_{1}^{2}}{2}\left\{\exp \left(\frac{4 \sigma^{2}}{\sigma_{1}^{2}}\right)-1\right\}\left(\frac{\pi}{2}-\alpha_{1}\right) \\
& \iint_{D_{3}} \exp \left(\frac{r^{2}}{\sigma_{1}^{2}}\right) r d r d \theta=\int_{0}^{2 \sigma} \exp \left(\frac{r^{2}}{\sigma_{1}^{2}}\right) r d r \int_{\alpha_{2}}^{\pi / 2} d \theta \\
& =\frac{\sigma_{1}^{2}}{2}\left\{\exp \left(\frac{4 \sigma^{2}}{\sigma_{1}^{2}}\right)-1\right\}\left(\frac{\pi}{2}-\alpha_{2}\right) \\
& \iint_{D_{2}} \exp \left(\frac{r^{2}}{\sigma_{1}^{2}}\right) r d r d \theta=\int_{0}^{\alpha_{1}} \int_{0}^{R(\theta)} \exp \left(\frac{r^{2}}{\sigma_{1}^{2}}\right) r d r d \theta \\
& =\frac{\sigma_{1}^{2}}{2} \int_{0}^{\alpha_{1}} \exp \left(\frac{4 \sigma^{2}}{\sigma_{1}{ }^{2}} \cos ^{2} \alpha_{1} \sec ^{2} \theta\right) d \theta-\frac{\sigma_{1}{ }^{2}}{2} \alpha_{1} \text { (付 • 9) } \\
& \text { ここにおいて, } R(\theta) \text { は付・図 } 2 \text { に示すように, } \\
& R(\theta)=2 \sigma \cos \alpha_{1} \sec \theta \\
& \begin{array}{l}
\iint_{D_{4}} \exp \left(\frac{r^{2}}{\sigma_{1}}\right) r d r d \theta=\int_{0}^{\alpha_{2}} \int_{0}^{R(\theta)^{\prime}} \exp \left(\frac{r^{2}}{\sigma_{1}{ }^{2}}\right) r d r d \theta \\
\quad=\frac{\sigma_{1}{ }^{2}}{2} \int_{0}^{\alpha_{2}} \exp \left(\frac{4 \sigma^{2}}{\sigma_{1}{ }^{2}} \cos ^{2} \alpha_{2} \sec ^{2} \theta\right) d \theta-\frac{\sigma_{1}{ }^{2}}{2} \alpha_{2} \text { (付 · 11) }
\end{array}
\end{aligned}
$$

(付・11) 式の $R(\theta)^{\prime}$ は, 付・図 2 より同様任,

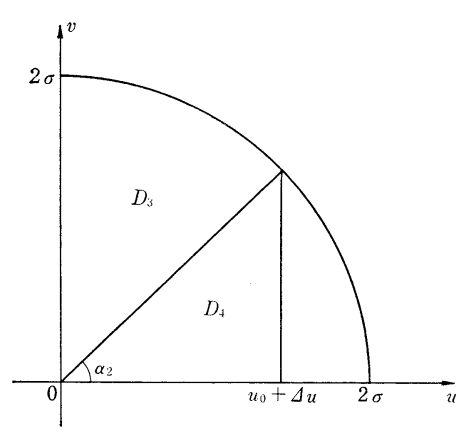

付 - 図 1 積分領域の分割

The division of the integral region, 

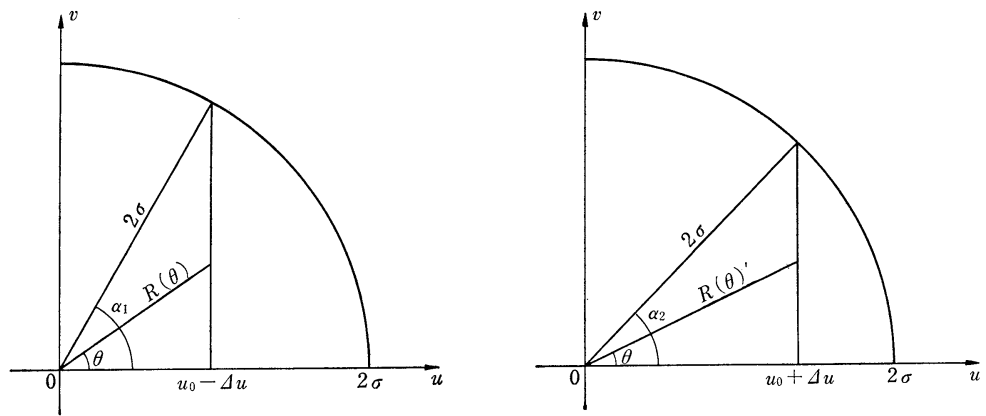

付・図 $2 R(\theta)$ および $R(\theta)^{\prime}$ の説明図

The explanation of $R(\theta)$ and $R(\theta)^{\prime}$.

$$
R(\theta)^{\prime}=2 \sigma \cos \alpha_{2} \sec \theta \quad \text { (付 · 12) }
$$

したがって，(付・6)，(付・7)，(付・8)，(付・9）,

（付・11）式より雑音パワー $N_{t 1}$ は求まる。つまり,

$$
N_{t 1}=A_{1} \sigma_{1}^{2}\left\{\exp \left(\frac{4 \sigma^{2}}{\sigma_{1}^{2}}\right)\left(\alpha_{1}-\alpha_{2}\right)\right.
$$

$$
\begin{aligned}
& +\int_{0}^{\alpha_{2}} \exp \left(\frac{4 \sigma^{2}}{\sigma_{1}{ }^{2}} \cos ^{2} \alpha_{2} \sec ^{2} \theta\right) d \theta \\
& \left.-\int_{0}^{\alpha_{1}} \exp \left(\frac{4 \sigma^{2}}{\sigma_{1}{ }^{2}} \cos ^{2} \alpha_{1} \sec ^{2} \theta\right) d \theta\right\}
\end{aligned}
$$

新講座連載予告

\section{〔講座〕 半導体物性とデバイス}

昭和 47 年 5 月以来 9 回にわたり連載いたしました「雑音」は本年 6 月号をあちまして終了いたしますが, 7 月からは標記新講座を下記のとおり 11 回にわたって連載いたします.引き続きご愛読のほどお願いいた します。

（表 題）

第 1 回 半導体物性概論

第 2 回 半導体材料の性質

第 3 回 半導体素子の特性

第 4 回 半導体素子の特性

第 5 回 プロセス技術 (1)

第 6 回 プロセス技術

第7回 IC, LSI の現状

第 8 回 デバイスの評価

第 9 回 テレビ用部品としての半導体

第10回 新しい話題

第11回 新しい話題
(筆 者)

青木 昌治（東大）

山田 祥二（静大）

尾沢修 (東芝)

久留勇 (東芝)

前田 敬二(東芝)

橋本 哲一（日立）

芦川 幹雄（日立）

倉田 一宏（日立）

松倉 保夫 (日電)

柴田 明一 (ソニー)

未定

未定

未 定
（掲載予定）

48年 7 月

8 月

9 月

10月

12 月

49年 1 月

2 月

3 月

5 月

6 月

8 月

（注）昭和 48 年 11 月， 49 年 4 月， 49 年 7 月は特集号となりますので，本講座は休載いたします。なお，表題および筆者 は変更されることがありますのでで了承ください. 